\title{
Local Labor Empowerment Model And It's Implication To Subjective Welfare And Employee Global Capability: A Study On Mining Area, At East Luwu, South Sulawesi, Indonesia
}

\author{
I Dewa Bagus Sugata Wirantaya \\ Ph.D scholar, Post Graduate School of Economics \\ Hasanuddin University \\ South Sulawesi, Indonesia \\ Eka Afnan Troena \\ Professor of Economics, Post Graduate School of Economics \\ Brawijaya University \\ East Java, Indonesia \\ Abd. Rahman Kadir \\ Professor of Economics, Post Graduate School of Economics \\ Hasanuddin University \\ South Sulawesi, Indonesia \\ Indrianty Sudirman \\ Ph.D of Economics, Post Graduate School of Economics \\ Hasanuddin University \\ South Sulawesi, Indonesia \\ DOI: 10.31364/SCIRJ/v6.i12.2018.P1218592 \\ http://dx.doi.org/10.31364/SCIRJ/v6.i12.2018.P1218592
}

\begin{abstract}
This study aims (i) to understand the historical background of the success of local labor in the mining area in East Luwu; (ii) to understand the perceptions of local labor in the formation of subjective well-being to increase work productivity; and (iii) forming and explaining the model of developing local labor to be able to compete globally. This research is a study that uses exploratif qualitative methods. Samples of several national and multinational heavy equipment maintenance service companies in East Luwu Regency, South Sulawesi, with 8 informants / participants (local labor). This type of qualitative research is a case study by evaluating or analyzing deeply the issue of empowering local labor. The data analysis technique used in this qualitative research is combined between the Cresswell and the Spradley to analyze the domain and taxonomic analysis models of the interviews. The results of this study indicate that the success of local labor in national companies and MNCs is determined by recruitment, training, career development, fairness in the company and local empowerment. Subjective well-being is obtained through increasing the position of local labor, increasing the ratio of local labor use, and the ability of local workers with global standards. The development of local resources is carried out through the application of low socio-economic status domains, the domain of chauvinism, and the domain of the availability of structured training or development so that local labor becomes human resources that can compete at the global level. An effective model of empowering local labor can improve subjective well-being and attitudes of chauvinism and encourage the achievement of global competitiveness and performance improvement.
\end{abstract}

Index Terms - local base recruitment, subjective wellbeing, multinational company, chauvinism, and empowerment

\section{INTRODUCTION}

Job opportunity problems are still a major problem in regional welfare equality. Government intervention is needed because gaps cannot be overcome through the people's own efforts. One way to take is to encourage national and multinational companies to 
carry out operations in the regions to empower local communities. Employers expect to recruit individuals who are ready to work (competently) from local sources (Brady, 2009). This will reduce the costs of paying for labor that is imported from other regions (including expatriates) and can eliminate the costs of providing accommodation for the workforce brought in.

The company is faced with the phenomenon of the quality of local human resources which is low, especially if the company is a multinational company with high expertise. The low quality of local resources forces companies to also carry out long-term investment activities in the form of training and development to improve the ability of their own local workers. The company must make efforts to produce high-competent local labor with lower costs than the cost of bringing in HR from outside the region.

Multinational Corporation is seen as positive as a potential catalyst for creating prosperity for the poor (Ansari et al, 2012). They have a lot of money to share with the poor who need it, both directly through CSR actions and through the establishment of local employment. They can also sell their goods to local people at a friendly price, even though fair prices prove difficult to determine (Reinecke, 2010), or provide soft loans for businesses so that they get more financial benefits from their activities.

This leads to the views of international institutions and the government that MNCs assume responsibility for the welfare of society both economically, socially and environmentally (Scherer and Palazzo, 2011) because they are more capable of government in upholding basic human rights and are also able to coordinate various economic-based resources spread across various countries without having to go through international relations procedures (Ansari et al, 2012). MNC should also be able to easily manage people's welfare because according to its name, it has been able to manage the welfare of its workforce to be able to develop on a global scale (Ansari et al, 2012).

There is also a negative view that MNC does not create welfare for the poor and also does not provide benefits to the company. The actions of MNCs within the local community actually produce non-essential expectations rather than meeting the basic needs of the community (Ansari et al, 2012). Furthermore, the presence of MNCs in the midst of the poor is seen as a corporate intervention for people's lives (Arora and Romijn, 2012). There are also those who see that there is no convincing scientific evidence that the MNC is truly capable of lifting the economy of local communities beyond the traditional institutions that have previously existed in these communities.

Ansari et al (2012) then build four types of relationships between MNC and the welfare of local communities, one of which is based on the dimensions of binding social capital and connecting social capital. The worst case is when MNC actually erodes both types of social capital resulting in congestion in the development of local welfare. When MNCs are able to build social capital attachments but not bridging social capital, MNCs exploit local communities as a source of cheap labor. MNCs can also build bridging social capital but erode attachment social capital, for example by taking local community members to be employed in other branches outside the region.

This makes local people lose their members little by little and ultimately unable to grow and develop. Ideally, MNC is able to raise both dimensions of social capital and produce a capability building that empowers local communities so that they are able to rise economically and psycho-sociologically. This is for example done through collaboration with community leaders, NGOs, and the government through CSR activities, rather than providing a portion of local labor that only involves companies and communities (Sanchez and Ricart, 2010; Rivera-Santos and Ruffin, 2010; Delios, 2010). This study aims (i) to understand the historical background of the success of local labor in the mining area in East Luwu; (ii) to understand the perceptions of local labor in the formation of subjective well-being to increase work productivity; and (iii) forming and explaining the model of developing local labor to be able to compete globally.

\section{LITERATURE REVIEW}

\subsection{Empowerment of Workers}

Bauer and Dolan (2011) put forward a list of a number of theories that can be applied in analyzing the relationship between companies and families in rural communities in empowering workers. One of the theories put forward is the theory of social capital. The theory of social capital states that a network of relationships between humans is a valuable resource for carrying out various social affairs, by providing shared capital which is the welfare of each member (Hult, 2011: 522). In line with this, Ansari et al. (2012) emphasize the importance of social capital theory in analyzing the relationship of corporate actions and contributions to society.

The stakeholder management theory is also expressed in the relationship between corporate intervention in the community and the economic performance of the company itself. According to stakeholder management theory, each company has an explicit and implicit relationship to various primary and secondary stakeholders who have strength or interest in the actions and results of the company. Therefore, relationships with these stakeholders are important for the survival of the company (Salama et al, 2011). In fostering relationships with stakeholders, companies are required by the local government to recruit workers from the local community, the dilemmatic facts faced by national companies and MNCs are the low quality of local resources so that companies must empower or increase the capability of the workforce to be able to meet competency standards needed through empowering workers when local workers have become employees of the company. 


\subsection{Employement}

According to the employment theory of Jahoda (in Paul and Batinic, 2010), and confirmed by Paul and Batinic's research (2010) except for status variables, people who work have a higher time structure, collective goals, social contacts, status, and activity than people who do not work and people who are not part of employment (students, households, and retirees). Individuals who do not work lose time structure, collective goals, social contacts, status, and activities and are carried away by stress because they are all associated with important psychological needs (Richards et al, 2016).

\section{a. Time structure}

The structure of time is structuring time to fill the day with planned activities (Paul and Batinic, 2010). The time structure is formed by social institutions from an early age starting from early childhood education. Some people began to enter the time structure during elementary school. In order for the time structure to be maintained, a thought emerged to make education lifelong (Hwang and Seo, 2012) if indeed someone did not get a job after graduating from primary and secondary education. This is done so that individuals do not experience the boredom and time perception that are in vain due to loss of time structure in their lives (Paul and Batinic, 2010).

b. Collective purpose

The collective goal is "feeling beneficial, needed by others, and feeling that collective interests are higher than individual interests" (Paul and Batinic, 2010). Work activities produce collective goals because someone becomes something for other people's goals and often this is done together in one organization, such as a company so that it becomes a common goal. The importance of this in modern society is shown by the emergence of the logotherapy paradigm in psychology that seeks to address the problem of feeling meaningless in humans, due to the loss of higher life goals than mere personal interests (Frankl, 2010). One technique in logotherapy is to look for this higher meaning of life (self transcendence) so that one's life is more meaningful. The basic human need is the need to be meaningful to others and without it, humans lose the spirit of life. This was based on observations in Nazi concentration camps where people who had collective goals were the ones who were most able to survive Nazi torture compared to people who did not have a collective goal.

c. Social contact

Social contact reflects the human need for social relations. Social contact is "shared experience and contact that is shared regularly with people outside the nuclear family" (Paul and Batinic, 2010). The theory of social capital states that social networks between people have value, as well as physical capital and human capital, in the form of providing social relations to find work, get new opportunities, and benefit from social support (Ewing et al, 2016). Work provides social contact for someone so that even feeling insecure in the work that has been carried out is able to create stress (Çinar et al, 2014).

d. Status

Social status is the position of someone in the community. Social status determines the formation of one's identity. Therefore, it becomes an important issue in existential psychology so that it is better for someone to have a low social status in society than without social status at all. Loss of social status results in a person experiencing psychological distress which results in disability.

e. Activity

Activities are steps to carry out activities to fill time and stay busy all the time. This allows a person to be someone who uses the body that he has. Work provides an activity function for someone. Without work, a person becomes passive and passive giving rise to social and psychological pressure because it is seen as not useful by society and causes individuals to feel bored, which in turn results in psychological disability. This explains why unemployed people are sometimes more active at night so they don't meet many people who are busy doing activities during the day. Literature also shows that employment activities in the community have a positive impact on social welfare in the community (Bazzhina, 2015).

\section{RESEARCH METHODS}

This research is a qualitative research with ethnographic methods. Ethnographic research is also called qualitative inquiry, researchers analyze the empowerment of local labor through primary data collection, observation data, and in-depth interviews. Ethnographic qualitative research is divided into several stages in data collection and carried out sequentially (Cresswell, 2014). The first stage determines the right informants by collecting several biography and selecting local workers who already have global standard criteria. The second stage, determining the interview grid to dig up information based on studies of theories and other empirical research. The third stage, conducting in-depth interviews with selected informants, then doing the narration of the interview results in dialogical texts.

Before conducting data collection, the researcher first conducts research settings by determining the location of the study, selecting the relevant companies, and determining who are the key informants in qualitative research. The types of data to be collected are all information relating to the pre-selection of local workers, the process of selecting local workers, the development of local workforce, the individual characteristics of each local workforce, the views and efforts of community leaders in fighting for local labor rights, perceptions or judgments of community leaders regarding the role of each company in empowering local workers, local government efforts in developing and creating regulations for empowering local labor, the strategies of each company in empowering

wWW.scirj.org

(C) 2018, Scientific Research Journal

http://dx.doi.org/10.31364/SCIRJ/v6.i12.2018.P1218592 
workers local, and fulfillment of local workforce competencies in global competencies. Primary data is obtained by means of interviews (in depth interviews) and secondary data sources from local government documents, company documents, or public documents. The selected companies are MNC or national heavy equipment maintenance services operating in East Luwu Regency.

\section{RESULTS AND DISCUSSION}

\section{Domain: structure of society with a low socio-economy}

The large number of employees with low SES implies that the environment around the company that is the source of local HR supply has low economic characteristics. This should be common in areas far from the center of economic growth in developing countries. South Sulawesi, especially the Soroako region, is a district that is far from the center of economic growth from Makassar, especially from Jakarta. As such, it is not surprising that the background of some research sources is that of people with low socioeconomic.

Local workers have the potential and competence that can compete at national and global levels. The characteristics of local workers include backgrounds from poor families, migrants, and other limitations. Looking closely at the history of local base recruitment by national companies and MNS towards informants. The results were obtained that the informants when completing their education at the diploma level, immediately took part in the selection in one of the companies that required the sons of the region, and other formal requirements. The majority of informants who managed to become employees were due to the company's collaboration with educational institutions to get potential prospective employees.

\section{Domain: local-based recruitment}

Local-based recruitment is a gateway for empowering local employees. It is possible for companies to recruit on a national scale but MNC companies have an obligation to fulfill commitments to local governments to accept local labor so that long-term sustainability operates. As part of balancing MNC's commitment and the quality of local workforce, MNC companies create scenarios of target schools through CSR programs, on the one hand fulfill CSR responsibilities and on the other hand get quality local workforce seeds.

A logical consequence if you want to get local HR, then recruitment is also done locally. The fact that recruitment by the company is free of charge certainly encourages many applicants with low socioeconomic to enter. But the main advantage is not in the free recruitment system, but at the location of the recruitment. The placement of the recruitment location itself is an important factor in starting the empowerment of local HR. Although it looks intuitive and simple, local-based recruitment that prioritizes behavior is a powerful way to empower local employees. Local-based recruitment provides empowerment for high school graduates in the region to see that their future is brighter with good income and better social status.

The recruitment process basically seeks or attracts prospective employees to be selected as employees according to the company's needs. Since the recruitment process is locally based on the domain of local communities, the main conditions for being recruited are local people. The conditions for being declared a local person are to include a local residence indentification card, in this case the East Luwu Regency residence indentification card. Recruitment processes must also accommodate local interests starting from the location of the announcement, the scope of the applicant's area, and the conditions for joining the recruitment must also accommodate the capacity or ability of existing local people.

It is impossible for a company to recruit employees from local people with the minimum requirements for undergraduate education, while it has been known that the characteristics of local workers come from low socioeconomic groups with a background in general or vocational high school education. Recognition of local acceptance must also be carried out simultaneously in all regions of local empowerment through existing local community media such as announcement in the sub-district office, village announcement boards, and so on. Thus, all prospective workers get the same information.

Basically there are two types of local-based recruitment, namely closed recruitment which is done by limiting participants through the target schools and open recruitment by providing the opportunity for all local people who fulfill the requirements to participate in the selection process. Both types of recruitment were found in this study. Particularly for closed recruitment through target schools carried out in several ways including:

- The Coops program, namely local students who are studying in the final semester, are given the opportunity to work while studying at MNC companies for approximately 6 months and in the future get priority to be accepted at MNC companies because their capabilities are known during Coops.

- On Job Training ie MNC companies collaborate with several vocational schools and final semester students usually carry out practical work during a certain period and during on-job training an assessment is carried out which later as a reference for superior seeds if there is employment.

- The Apprentice Program is the company's need for future labor needs due to retirement reasons or business development of the company so that the company deliberately filters the target school alumni then is educated on basic technical 
training, leadership and behavior for a certain period. Before being accepted as an apprentice participant, prospective participants must sign an agreement that after completing apprentice they do not guarantee that they will be accepted as workers in MNC companies because the company continues to consider aspects of company strategy. With the dynamic condition of the company environment, it does not rule out the possibility that the future labor needs will actually be in the form of a reduction in labor force so that graduates of apprentices are canceled to be recruited. For this reason, apprentice participants besides being educated are also given pocket money as compensation for studying while working in the company. Priority of graduating apprentices received at the company starts from the best ranking, because of the limited number of workforce needs, for apprentice participants who have not been accepted will be used as a pipeline for a certain period of time to be called as labor if there are additional labor requirements in the company .

- School recruitment is an MNC company intentionally selecting prospective employees sourced from the target schools because the alumni of the target schools are believed to have the best quality among the local workforce.

MNC companies are committed to local governments to prioritize local workforce to be accepted as employees in the company, but if there are no skilled workers in the local area, MNC companies are given the authority to bring in non-local workers. To ensure this MNC commitment can be fulfilled properly, each MNC must have standard procedures in the process of tiered recruitment by prioritizing local workforce (empowerment areas), South Sulawesi regional, then new to National or Expat if both locally and regionally no skilled staff is needed.

The regional government itself has procedures in protecting and ensuring that every workforce recruitment at MNC companies has prioritized local workforce and the process is carried out transparently and fairly. Every recruitment must first report to the Luwu Timur Manpower Office to make a filter to ensure the availability of the required labor qualifications, announcements in the empowerment area, selection process from the file to technical selection, and after passing the selection must take care of permission to work as a workforce in Kab. East Luwu. Thus, the local government has filtered from the beginning of the process to the end of the local recruitment process.

MNC's commitment to local government in terms of local labor recruitment raises opportunities for local communities to form organizations (forums) or local companies as outsourcing labor services. As a business entity, MNC companies will tend to cooperate more with business entities, namely companies providing labor services for reasons of governance and certain contract periods. Taking into account social risks in the recruitment process if through local labor suppliers is to cause smaller risks and faster processes, MNC companies partially fulfill the workforce needs through an outsourcing model by partnering with local labor supply entrepreneurs so that mutualism occurs between MNC companies with local entrepreneurs.

As a result of mutualism between MNC companies and local entrepreneurs, the forums felt that they were set aside so that the forums also requested quota or quota so that members were accepted in MNC companies or local companies providing labor services in each workforce. On the other hand, these forums have a supporting period power which often demonstrates if they do not get a quota at each reception. Attractiveness or competition between forums and local labor service providers leads to a reduction in the quality or capability of uncontrolled candidates for local labor so that many local workers are forced to be accepted in MNC companies with capabilities that are lower than the stipulated requirements.

MNC companies as users of local labor cannot refuse this because of pressure from forums so that members can be accepted as workers and avoid social upheaval such as demonstrations carried out by supporters of forums. The domain of local-based recruitment can be expanded by placing the relationship of the domain details on as in each sub domain as shown in the following figure 1.

Fulfillment of MNC commitments to stakeholders (Government and community)

\section{Local Business} Partnership irj.org Research Journal http://dx.do1.org//0.31364/SCIRJ/v6.i12.2018.P1218592 
Figure 1. Partial Model of Domain Based Local Recruitment

\section{Domain: local workforce development}

One indicator that shows the success of the local employee development program is that local employees themselves have occupied several important positions in the company. This happens because local employees themselves get the opportunity to develop their careers either starting from acting or leading special projects and given justice between local and non-local employees in terms of training. Equitable training is characterized by transparent judgments between local employees and non-local staff and open communication between superiors and subordinates regardless of where employees are recruited. The mentorship function was also found in this study and was very helpful in guiding local employees, both internal and external mentors. When local employees have been given trust in important positions, this also indicates an increase in local employee authority in the company. The company will provide increased authority if local employees themselves have shown independence in work, are able to work well together in the team, and succeed in resolving work challenges.

One other interesting finding in this study is that almost all informants revealed that the ratio of local employees from year to year is increasing. Increasing the number of local employees in MNC companies as other indicators of the success of empowering local workers, This success is caused by: (i) the increasing number of ready-to-use workers available in the local area as a result of the local workforce receiving skills training from non-formal education such as training centers work and process of sharing experience or skills among fellow local workers, (ii) increasing the trust of MNC Companies to the quality of local workers as a source of employees who are ready to use. This increase in trust is because some local workers who have successfully assumed important roles 
have become role models by companies to dismiss the notion of low quality local employees and some local workers have good commitments when given special responsibilities or tasks, and (iii) the role of government and community leaders in selecting strictly the inclusion of non-local labor, in the sense of a local workforce that is given the first priority in every recruitment and the active role of community leaders in monitoring the arrival of non-local labor in their area.

Another indicator of the success of empowering local workers found in this study is that some local employees already have global standards. This global capability can be achieved if MNC companies already have a structured development program that refers to global competency standards, the existence of inter-company benchmarking programs, mastery of foreign languages either through corporate media or enhancement of personal capabilities and which is no less important in supporting global capabilities. Active in social networks, especially professionalism and local employees are given the opportunity to take part in international competitions. In this social network, all local employees can interact with employees of similar companies anywhere operating in the world.

The success in developing local employees brings an outcome for that is fulfilled welfare both objectively and subjectively. The level of welfare is in the form of sufficient salary, a comfortable work location, company support to employees through social activities such as family catering, sports, etc., and the employees themselves get sufficient time to rest or leave. This objective and subjective well-being brings output in the form of job satisfaction and commitment of local employees to MNC companies that employ them. Based on the taxonomic analysis above, the domain diagram of local workforce development can be developed into the following figure 2 .

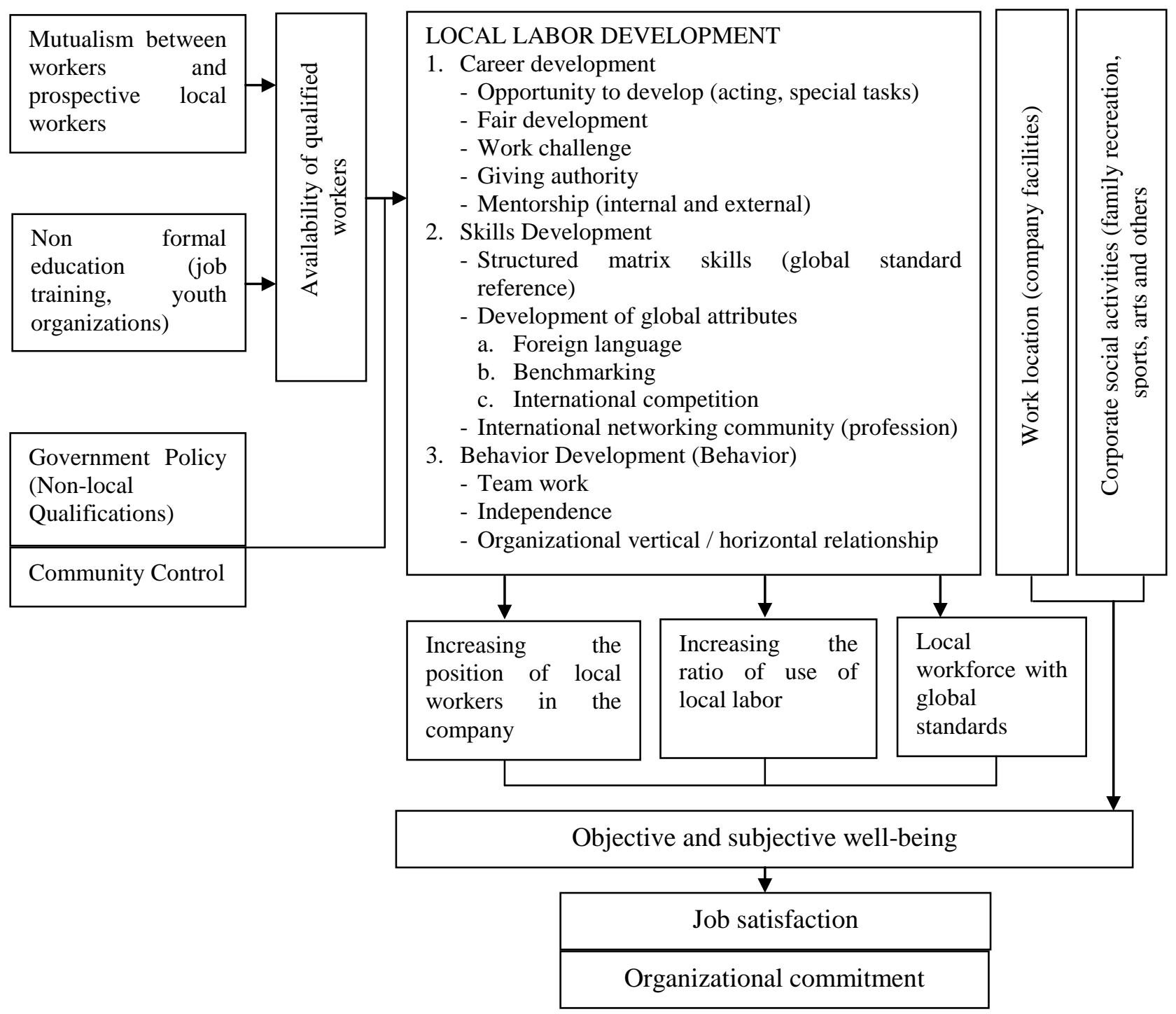

Figure 2. Partial model of the local workforce development domain

\section{Domain: Chauvinism}


There are three forms of chauvinism found in qualitative research that researchers call negative chauvinism, neutral chauvinism, and positive chauvinism. Negative chauvinism appears to be interviewed in the form of pride as a local son. Usually this results in a negative effect in the form of segregation between groups of native men and migrant groups. In some cases the opening of a new factory, chauvinism can take the form of demonstrations to prioritize regional sons to occupy top positions. But the effect produced is quite positive in a competitive environment such as in PT. Indotruck. Negative chauvinism encourages the speaker to achieve and occupy a high position in the company due to the belief that "the local son must lead his own area". The enthusiasm is the same, but the resource person uses the rules of playing based on professionalism to achieve it. Meanwhile, neutral chauvinism due to cultural impulses and positive chauvinism that is willing to accept for certain purposes also encourages the development of local workforce to be successful.

Negative chauvinism arises because of individual vertical attitudes that perceive they to be better than others. The ethnocentrism view makes one look at another culture by doing a measure of the culture they have. While neutral chauvinism puts forward the cultural factors found by researchers is the Padoe Culture which considers all people to be united so that all goals can be achieved. Likewise positive chauvinism is an attitude that is more coopera- tive and flexible towards culture or outsiders, but with certain goals such as gaining transfer of knowledge, desire to win something, and so on. Based on the taxonomic analysis above, the Chauvinism domain diagram can be developed into the following figure 3 .

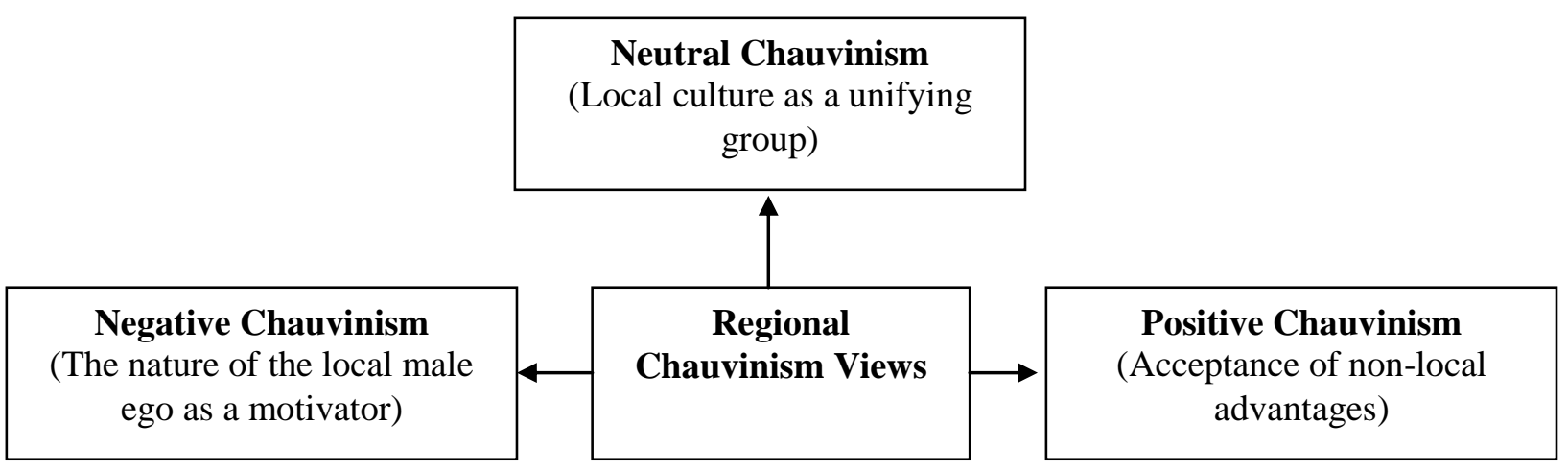

Figure 3. Domain details diagram in the domain of Chauvinism

\section{The model of empowering local labor and its implications for subjective well-being and global capabilities of the workforce}

Merging between domains, semantic relations, and sub domains is very important to form a model of empowering local labor and its implications for subjective well-being and global capabilities of the workforce. The model is the main finding of this study which scientifically collaborates across central themes that are associated with previous research and established theory. The full model is presented in below.

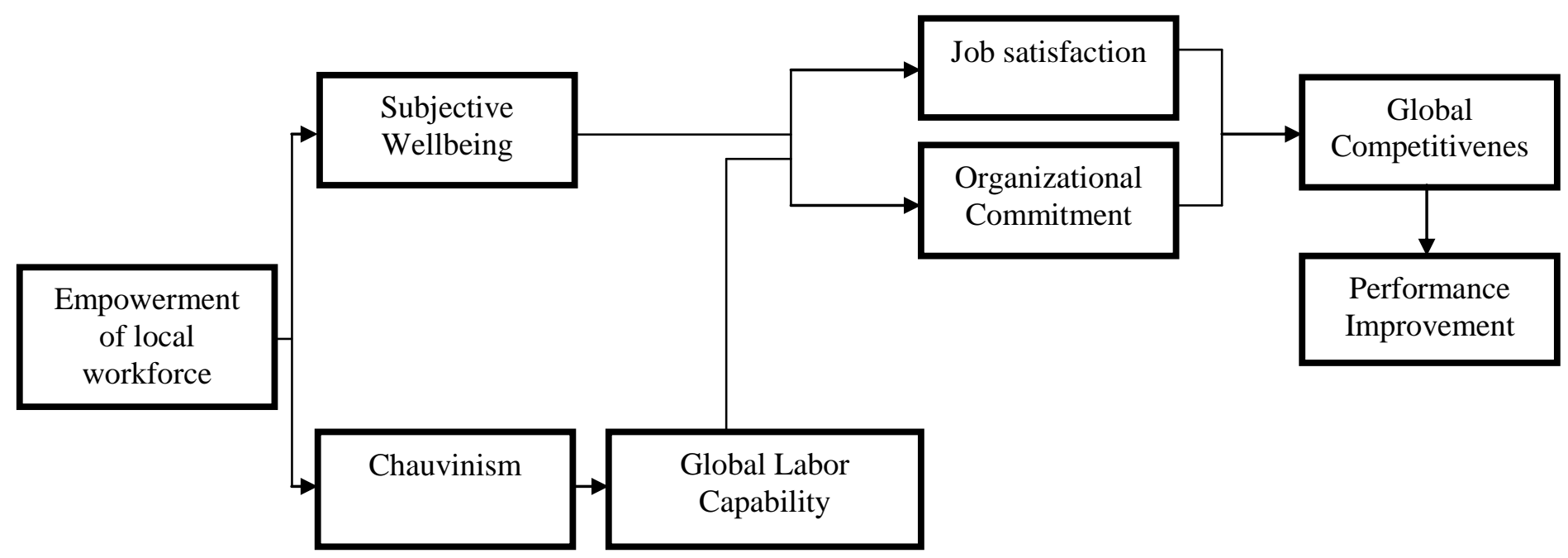

Figure 4. The model of empowering local labor in subjective well-being and global capabilities of the workforce

Empowerment of local workforce. This factor consists of several sub domains namely (a) recruitment; (b) key positions in the company; and (c) increase the ratio of local labor. The key factors in empowering local workers have been proven effective and targeted in changing the quality of local workers who generally have various limitations to become professional workers who have 
high integrity. Chauvinism. This factor consists of several sub domains namely (a) positive chauvinism; (b) neutral chauvinism; and (c) negative chauvinism. The interview results from all informants that the chauvinism they have with different orientations can actually make it easier for them to achieve success in the company. The effectiveness of chauvinism in the organization is realized if it is supported by the empowerment of local workers.

Subjective well-being. This factor consists of (a) joyful feelings; and (b) achieving life goals. The interview results from all informants that chauvinism contributed to increasing job satisfaction and commitment to the company. Ryan and Deci (2000) explain the effects of the quality of employment of local workers that can affect the increase in subjective well-being. Theoretically, subjective well-being serves to measure individual satisfaction with living standards, health, achievement in life, relationships, security, community relations, and security in the future (Stanley et al, 2011). All indicators are psychological and depend on internal and external factors.

Global capability of the workforce. This factor consists of (a) mastery of a foreign language; (b) benchmarking; (c) international competition; and (d) professional international social networks. All informants explained that global capability would be easily achieved if MNC and national companies had a structured local workforce development program with reference to global competency standards, implemented cross-company benchmarking programs, foreign language mastery, active role of local workforce in professional social networks. The company provides opportunities for local workers to take part in international competitions. The interview results from all informants that one of the factors that influence the increase in global capabilities of local workforce is chauvinism.

\section{CONCLUDING REMARKS}

The success of local labor is motivated by the historical characteristics of local labor, historically the recruitment of local bases by national companies and MNCs. After becoming a permanent employee, the company then develops competencies towards local workforce in the form of on-job training and is given education and training to add knowledge and skills that are in line with the position of employees in the company. Other forms of competency development in the form of career development for local workers. Subjective well-being is obtained by local labor through increasing the position of local labor, increasing the ratio of local labor use, and the ability of local workers with global standards. Subjective well-being makes local workers live in conditions that are quite ideal, and the achievement of life goals. Subjective well-being also has a major impact on increasing job satisfaction and organizational commitment.

The development of local resources is carried out through the application of a low socio-economic status domain, the domain of chauvinism, and the domain of the availability of structured training or development. The domain of low socio-economic status as a description of local labor is viewed in terms of socio-economic as measured by education, parent work, and economic conditions. Chauvinism in this study is able to improve the quality of local workforce into professional workforce, then supported by the availability of structured training or development consisting of international standard references and reference to renewable technology has contributed greatly to the improvement of global capabilities.

The empowerment model of local labor is built from the recruitment of local bases, key positions in the company, and an increase in the ratio of local labor. Empowerment of local workforce results in subjective well-being, chauvinism, and global capabilities of the workforce that have an impact on increasing job satisfaction and organizational commitment to achieve global competitiveness and performance improvement. The role of the three pillars of cooperation (government, community leaders, and entrepreneurs) is very important in increasing the empowerment of local labor which is a control function of all irregularities that occur in the field, providing input for companies and the government in enhancing the empowerment of local workers.

\section{REFERENCES}

[1] Ansari, S., Munir, K., Gregg, T. (2012). Impact at the 'Bottom of the Pyramid': The Role of Social Capital in Capability Development and Community Empowerment. Journal of Management Studies, 49(4), pp: 813-842.

[2] Arora, S., \& Romijn, H. (2012). The empty rhetoric of poverty reduction at the base of the pyramid. Organization, 19(4), pp 481-505.

[3] Bauer, J. W., \& Dolan, E.M. (2011). Theories for Studying Rural Families and Work. J. W. Bauer, E. M. Dolan (eds.), Rural Families and Work. International Series on Consumer Science, 1. 17-36.

[4] Bazzhina, V. (2015). Labour Activity as a Factor of Social, Economic and Emotional Well-being of the Population. ProcediaSocial and Behavioral Sciences, 166, 74-81.

[5] Brady, Robert P. (2009). Work readiness inventory administrastartor's guide. JIST Works.

[6] Çınar, O., Karcıoğlu, F., \& Aslan, İ. (2014). The relationships among organizational cynicism, job insecurity and turnover intention: A survey study in Erzurum/Turkey. Procedia-Social and Behavioral Sciences, 150, 429-437.

[7] Creswell, J. W. (2014). Research Design: Qualitative, Quantitative and Mixed Methods Approaches (4th ed.). Thousand Oaks, CA: Sage. 
[8] Delios, A. (2010). How Can Organizations be Competitive but Dare to Care?. Academy of Management Perspectives, 24-35.

[9] Ewing, R., Hamidi, S., Grace, J. B., \& Wei, Y. D. (2016). Does urban sprawl hold down upward mobility?. Landscape and Urban Planning, 148, 80-88.

[10] Frankl, V. E. (2010). The feeling of meaninglessness: A challenge to psychotherapy. American Journal of Psychoanalysis, 32(1), 85.

[11] Hult, G.T.M. (2011). Toward a theory of the boundary-spanning marketing organization and insights from 31 organization theories. Journal of the Academy of Marketing Science, Vol. 39, Issue 4, pp: 509-536.

[12] Hwang, D. (2012). Policy Implication of Lifelong Learning Program of EU for Korea. Procedia-Social and Behavioral Sciences, 46, 4822-4829.

[13] Paul, K. I. \& Batinic, B. (2010). The need for work: Jahoda's latent functions of employment in a representative sample of the German population. Journal of Organizational Behavior, 31, 45-64.

[14] Reinecke, J. (2010). Beyond a subjective theory of value and towards a 'fair price': an organizational perspective on Fairtrade minimum price setting. Organization, 17(5), 563-581.

[15] Richards, D., Richardson, T., Timulak, L., Viganò, N., Mooney, J., Doherty, G., \& Sharry, J. (2016). Predictors of depression severity in a treatment-seeking sample. International Journal of Clinical and Health Psychology.

[16] Rivera-Santos, M., \& Rufín, C. (2010). Global village vs. small town: Understanding networks at the Base of the Pyramid. International Business Review, 19(2), 126-139.

[17] Ryan, R.M., Deci, E.L (2000) Intrinsic and Extrinsic Motivations: Classic Definitions and New Directions. Contemporary Educational Psychology 25, 54-67

[18] Salama, A., Anderson, K., \& Toms, J. S. (2011). Does community and environmental responsibility affect firm risk? Evidence from UK panel data 1994-2006. Business Ethics: A European Review, 20(2), 192-204.

[19] Sanchez, P., \& Ricart, J. E. (2010). Business model innovation and sources of value creation in low-income markets. European Management Review,7(3), 138-154.

[20] Scherer, A. G., \& Palazzo, G. (2011). The new political role of business in a globalized world: A review of a new perspective on CSR and its implications for the firm, governance, and democracy. Journal of management studies,48(4), 899-931.

[21] Stanley, J. K., Hensher, D. A., Stanley, J. R., \& Vella-Brodrick, D. (2011). Mobility, social exclusion and well-being: Exploring the links. Transportation research part A: policy and practice, 45(8), 789-801.

[22] Zuhdan, M. (2014). Perjuangan Gerakan Buruh Tidak Sekedar Upah Melacak Perkembangan Isu Gerakan Buruh di Indonesia Pasca Reformasi. Jurnal Ilmu Sosial dan Ilmu Politik, Vol. 17, No. 3, 272-290. 